\title{
Characterization and partial purification of pectinesterase, a differentiation-specific enzyme of Uromyces viciae-fabae
}

\author{
Alexander K. Frittrang, Holger Deising and Kurt Mendgen* \\ Lehrstuhl für Phytopathologie, Fakultät für Biologie, Universität Konstanz, Postfach 5560, 7750 Konstanz, \\ Federal Republic of Germany
}

(Received 13 April 1992; revised 2 July 1992; accepted 10 July 1992)

\begin{abstract}
The differentiation-specific formation of three isoforms of pectinesterase by the broad bean rust fungus Uromyces viciae-fabae is described. Activity becomes detectable when substomatal vesicles are formed. In crude extracts isoform $A$ contributed $78 \%$ of the total pectinesterase activity, and isoforms $B$ and $C$ contributed $20 \%$ and $2 \%$, respectively. All three isoforms were found extracellularly in ratios identical to those in extracts. The isoelectric points of the pectinesterase isoforms were $8.4(\mathrm{~A}), 5.7(\mathrm{~B})$, and $4.7(\mathrm{C})$ as determined by chromatofocusing. Isoform $A$ had an $M_{\mathrm{r}}$ of 33500 and showed a distinct $\mathrm{pH}$ optimum at 6.0. The $M_{\mathrm{r}}$ of isoform $\mathrm{B}$ was 40000; its $\mathrm{pH}$ optimum ranged from 5.5 to 7.5. Due to its extremely low activity, isoform $C$ was not further characterized. The possible role of pectinesterases in the infection process of the broad bean rust fungus is discussed.
\end{abstract}

\section{Introduction}

Plant cell walls function as physical defence barriers to the ingress of pathogens. Consequently, a large variety of hemibiotrophic and necrotrophic fungi are thought to produce cell-wall-degrading enzymes in order to breach the host cell wall (Keon et al., 1987). Since pectin is the predominant carbohydrate polymer in primary cell walls, significant efforts have been made to elucidate the role of pectic enzymes in plant-pathogen interactions. Pectic enzymes are able to cause intensive tissue maceration (Bateman, 1976), and pectinesterase and pectinase are considered as virulence factors in Fusarium solani f. sp. pisi (Köller et al., 1982).

The production of cell-wall-degrading enzymes by obligate biotrophs such as powdery mildews and rust fungi has not been conclusively demonstrated. In an early study of cell-wall-degrading enzymes from Puccinia graminis var. tritici, a substrate-inducible pectinase was detected from uredosporelings after germination on an agar containing pectin (Van Sumere et al., 1957). However, the significance of this report remains questionable, since microbial contamination cannot be excluded on the basis of the data presented. Other investigators found limited amounts of cell-wall-degrading enzymes but no pectic enzymes in rusts and powdery

* Author for correspondence. Tel. 07531 883680; fax 07531883035.

Abbreviation: DTE, dithioerythritol. mildews. They concluded that growth of biotrophs through host walls is facilitated by glycosidases and glycanases rather than by pectic enzymes (Cooper, 1983, 1984; Keon et al., 1987). In studies dealing with rust fungi, only dormant spores, or structures that are formed on the leaf surface (i.e. germ tubes and appressoria), have been examined. Infection structures formed within the host mesophyll have not been analysed, although it has been shown that mRNA and protein synthesis change dramatically when appressoria and subsequent structures are formed (Deising et al., 1991; Hoch \& Staples, 1987).

Uredosporelings of the broad bean rust fungus Uromyces viciae-fabae form a series of infection structures in order to invade the leaf through stomata (Mendgen et al., 1988). When grown on inductive polyethylene sheets, germ tubes, appressoria, substomatal vesicles, infection hyphae and haustorial mother cells are formed in a time-dependent and synchronous fashion (Deising et al., 1991). The availability of specific stages of morphogenic differentiation of this fungus provides a tool for the investigation of physiological parameters involved in host-parasite interactions. For example, using this system (Deising et al., 1991), a polygalacturonate lyase was found when haustorial mother cells of $U$. viciae-fabae were differentiated (Deising \& Mendgen, 1992). The activity of this enzyme decreased with increasing degrees of methylation of the polygalacturonate substrate $(\mathrm{H}$. Deising, unpublished results). These 
data indicate the potential importance of pectinesterases in wall degradation caused by the broad bean rust fungus. The present report describes the partial purification and properties of different pectinesterases (EC 3.1.1.11) of U. viciae-fabae. The characteristics of the enzyme isoforms are compared with pectinesterases of non-biotrophic fungi.

\section{Methods}

Spore production. Uredospores of $U$. viciae-fabae (Pers.) Schroet. originated from a single spore line isolated from naturally infected plants. Uredospores were propagated on Vicia faba cv. con amore as described previously (Deising et al., 1991). Uredospores were immediately used or stored at $-70^{\circ} \mathrm{C}$ for subsequent analyses.

Production of infection structures. Approximately $150 \mathrm{mg}$ uredospores of $U$. viciae-fabae were dusted onto a scratched polyethylene sheet $(55 \times 34 \mathrm{~cm})$ (Deising et al., 1991). For controls (i.e. non-differentiated uredosporelings) polyethylene sheets were replaced by glass plates. Inoculated sheets or glass plates were misted with sterile distilled water and incubated at room temperature in the dark at $100 \%$ relative humidity. Sheets sprayed with a cycloheximide solution (1 or $10 \mu \mathrm{g}$ $\mathrm{ml}^{-1}$ ) were used to ensure the fungal origin of pectinesterase activity. Structures were harvested $24 \mathrm{~h}$ after inoculation unless otherwise indicated.

Preparation of enzyme extracts. Preparation of crude extracts. Prior to preparing extracts, germination rates and differentiation of infection structures were checked microscopically. Crude extracts were produced by homogenizing fungal germ tubes and infection structures (Potter-Elvehjem homogenizer; Kummer, Freiburg, FRG) or dormant spores (porcelain mortar) in $50 \mathrm{mM}$-ammonium acetate buffer (pH 6.0) containing $1 \mathrm{mM}$-PMSF and $1 \mathrm{mM}$-DTE at $4^{\circ} \mathrm{C}$. The homogenate was centrifuged $(24000 \mathrm{~g}, 20 \mathrm{~min})$ to remove cell wall fragments. The supernatant was frozen in liquid nitrogen and lyophilized.

Preparation of washing fluid of infection structures. To obtain extracellular proteins, polyethylene membranes with adhering differentiated structures were inverted and floated on $400 \mathrm{ml} 50 \mathrm{~mm}$ ammonium acetate buffer ( $\mathrm{pH} \mathrm{6.0)}$ ) for $10 \mathrm{~min}$. The washing fluid from 10 sheets was tested for activity of the cytoplasmic marker enzyme malate dehydrogenase to estimate the fraction of damaged structures. The washing fluid was frozen in liquid nitrogen and lyophilized.

Further treatment of extracts. The lyophilized material of the different extracts was resuspended in buffers as required for subsequent analyses and dialysed overnight. The dialysed material was centrifuged $(20000 \mathrm{~g}, 30 \mathrm{~min})$ to remove precipitates and either used immediately or stored in liquid nitrogen.

Enzyme assays. Pectinesterase was measured as described by Förster \& Rasched (1985) with minor modifications. One millilitre of a $2 \%$ $(w / v)$ aqueous solution of apple pectin type $\mathrm{B}(\mathrm{pH} 7.0)$ (Roth, Karlsruhe, FRG) and $1 \mathrm{ml} 10 \mathrm{~mm}$-PIPES (Roth) buffer (pH 7.0) containing $300 \mathrm{mM}-\mathrm{NaCl}$ were mixed. After adding $0.5 \mathrm{ml}$ enzyme extract (in $5 \mathrm{~mm}-\mathrm{PIPES}, 150 \mathrm{mM}-\mathrm{NaCl} ; \mathrm{pH} 7.0$ ) the $\mathrm{pH}$ decrease at $30^{\circ} \mathrm{C}$ was followed until a difference of at least 0.1 and maximally $0 \cdot 2 \mathrm{pH}$ units had been detected. In controls the enzyme solution was substituted by buffer. Another control contained distilled water rather than pectin. One unit of pectinesterase activity was defined as $1 \mathrm{nmol}$ of protons liberated per minute.

The $\mathrm{pH}$ optimum of pectinesterase was determined by adding $0.5 \mathrm{ml}$ of an aqueous enzyme solution or, in parallel controls, $0.5 \mathrm{ml}$ distilled water to $2 \mathrm{ml}$ of a non-buffered solution of $1 \%(\mathrm{w} / \mathrm{v})$ pectin at the respective $\mathrm{pH}$. The $\mathrm{pH}$ was continuously measured, and kept constant by titrating with $20 \mathrm{mM}-\mathrm{NaOH}$, for $1 \mathrm{~h}$. Both samples and controls were adjusted to $\mathrm{pH} 7.0$ with $\mathrm{NaOH}$ at the end of the assay. The difference in the required moles of $\mathrm{NaOH}$ corresponded to the moles of carboxyl groups formed as a result of pectinesterase activity.

Malate dehydrogenase (EC 1.1.1.37) activity was measured according to Sigma Technical Bulletin no. 340-UV. The assay was performed at room temperature by adding $100 \mu$ l sample to $2.9 \mathrm{ml}$ $100 \mathrm{~mm}$-potassium phosphate buffer containing $136 \mu \mathrm{M}-\mathrm{NADH}$ and $150 \mu \mathrm{M}$-cis-oxaloacetate (pH 7.5). The decrease in $A_{340}$ per minute was used as a measure of malate dehydrogenase activity.

Protein determination. Protein concentration was determined by using a commercially available protein assay (BioRad) based on the method by Bradford (1976), with $\gamma$-globulin as standard.

Column chromatography. Chromatofocusing. Chromatofocusing was performed on a DEAE Si $=500$ (Serva) column $(13 \mathrm{ml}$ gel bed, $16.8 \mathrm{~cm}$ long) in the $\mathrm{pH}$ range from $6 \cdot 2$ to 3.5 . The column was equilibrated with 25 mm-histidine (pH 6.2). Up to $4 \mathrm{ml}$ of sample in the same buffer was applied to the column and eluted with $0 \cdot 2 \%(w / v)$ Servalyt 3-8 (Serva) adjusted to $\mathrm{pH} 5 \cdot 0$, followed by $0 \cdot 2 \%(\mathrm{w} / \mathrm{v})$ Servalyt $3-8$ adjusted to $\mathrm{pH}$ 3.5. The column was then washed with $1 \mathrm{M}-\mathrm{NaCl}$. Fractions of $1.75 \mathrm{ml}$ were collected. The flow rate was $0.25 \mathrm{ml} \mathrm{min}^{-1}$.

A PBE 94 (Pharmacia) column (9 ml gel bed, $17.8 \mathrm{~cm}$ long) equilibrated with 25 mM-ethanolamine ( $\mathrm{pH} \mathrm{9.0)}$ ) was used for chromatofocusing in the $\mathrm{pH}$ range from 9.0 to 6.0 . In this case up to $3 \mathrm{ml}$ of sample in 25 mM-ethanolamine (pH 9.0) was applied to the column and eluted with $10 \%$ (v/v) Polybuffer 96 (Pharmacia), adjusted to $\mathrm{pH} \mathrm{6.0,}$ followed by washing with $1 \mathrm{M}-\mathrm{NaCl}$. Flow rate and fraction size were set as above.

The $\mathrm{pH}$ gradient was monitored using a $\mathrm{pH}$ microelectrode (type $\mathrm{U}$ 402-M3, Ingold, Steinbach, FRG) and the protein content of the fractions was estimated by determining the absorbance at $280 \mathrm{~nm}$.

Each fraction was dialysed against $5 \mathrm{~mm}$-PIPES containing $150 \mathrm{~mm}-$ $\mathrm{NaCl}\left(\mathrm{pH} \mathrm{7.0)}\right.$ overnight $\left(4^{\circ} \mathrm{C}\right)$ and prior to pectinesterase activity determination. Active fractions were pooled for further use.

Gel permeation chromatography of crude extracts. A Sephadex G75-SF (Pharmacia) column ( $378 \mathrm{ml}, 84 \mathrm{~cm}$ long) equilibrated with $150 \mathrm{~mm}$ $\mathrm{NaCl}$ in 5 mM-PIPES buffer (pH 7.0) was used for $M_{\mathrm{r}}$ determination of pectinesterase in crude extracts. A $2 \mathrm{ml}$ sample of crude extract was applied to the column and separated at a flow rate of $0.25 \mathrm{ml} \mathrm{min}^{-1}$. Fractions of $3.75 \mathrm{ml}$ were collected.

Gel permeation chromatography of separated pectinesterase isoforms. $M_{\mathrm{r}}$ determination of pectinesterase isoforms separated by chromatofocusing was performed by HPLC on a Polyol $\mathrm{Si}=100$ column $(4.6 \times 250 \mathrm{~mm}, 5 \mu \mathrm{m}$ pore size; Serva) equipped with a guard column $(4.6 \times 50 \mathrm{~mm}$, Polyol $\mathrm{Si}=100,10 \mu \mathrm{m}$ pore size; Serva). The columns were equilibrated with 5 mM-PIPES buffer containing $150 \mathrm{~mm}-\mathrm{NaCl}$ (pH 7.0). Samples of $20 \mu \mathrm{l}$ were injected and fractions of $100 \mu \mathrm{l}(0.2 \mathrm{ml}$ $\mathrm{min}^{-1}$ flow rate) were collected. Identical fractions of six runs were pooled to assay pectinesterase activity and to measure the protein content. Bovine serum albumin (BSA, $M_{\mathrm{r}} 67000$ ), egg albumin (45000), carbonic anhydrase (29000), and cytochrome $c(12300)$ served as $M_{\mathrm{r}}$ markers.

Polyacrylamide gel electrophoresis. SDS-PAGE was performed according to Laemmli (1970) using slab gels containing $12 \%$ (running gel) and $4 \%$ (stacking gel) polyacrylamide. Gels were run at a constant current of $15 \mathrm{~mA}$ (stacking gel) and $30 \mathrm{~mA}$ (running gel). Silver staining as described by Jungblut \& Seifert (1990) was used to visualize separated proteins.

Reproducibility of results. Within a series of experiments, portions of spores collected at the same time were used. Each set of experiments was performed at least twice using spores harvested at different times. All tables and figures show representative values. 


\section{Results}

\section{Differentiation specificity of pectinesterase}

In crude extracts of $U$. viciae-fabae, pectinesterase activity was first detected when uredosporelings began to differentiate substomatal vesicles, and activity increased during the formation of infection hyphae and haustorial mother cells. In extracts of germ tubes grown on glass plates for $24 \mathrm{~h}$ (non-differentiated controls), pectinesterase activity was not found. Spores treated with cycloheximide produced only short irregularly shaped germ tubes and did not express any pectinesterase activity (Fig. 1).

\section{Separation and quantification of pectinesterase isoforms from crude extracts by chromatofocusing}

Chromatofocusing of crude extracts of 24-h-old infection structures in the range from $\mathrm{pH} 6.4$ to 3.5 revealed major pectinesterase activity in fractions that did not bind to the column. Two minor isoforms bound to the column and eluted at $\mathrm{pH} 5.7$ (isoform B) and 4.7 (isoform C). Enzyme peaks co-eluted with major protein peaks. The addition of $\mathrm{NaCl}$ did not elute any further pectinesterase activity (Fig. 2). The unbound fractions contained only one pectinesterase isoform as judged by subsequent chromatofocusing on PBE 94. The pI of this isoform (A) was 8.4 (Fig. 3).

In crude extracts of 24 -h-old infection structures, $78 \%$ of the total pectinesterase activity consisted of isoform A, $20 \%$ of isoform B and $2 \%$ of isoform C.

\section{Separation and quantification of pectinesterase isoforms from washing fluid by chromatofocusing}

Washing fluid prepared from infection structures that had differentiated for $24 \mathrm{~h}$ contained $50 \%$ of the total pectinesterase activity, but only a minor percentage of the total amount of protein and negligible amounts of malate dehydrogenase activity (Table 1 ). In washing fluids of 24-h-old infection structures the ratios of the three isoforms were identical to those reported for crude extracts (data not shown).

\section{Characterization of pectinesterase isoforms}

Chromatography of crude extracts on Sephadex G75-SF showed a pectinesterase activity peak corresponding to an $M_{\mathrm{r}}$ of 35000 , but the different isoforms could not be separated (data not shown). On Polyol $\mathrm{Si}=100$ the pectinesterase isoforms separated by chromatofocusing exhibited $M_{\mathrm{r}}$ values of 33500 (isoform A) and 40000 (isoform B) (data not shown). Isoform C was not further characterized.

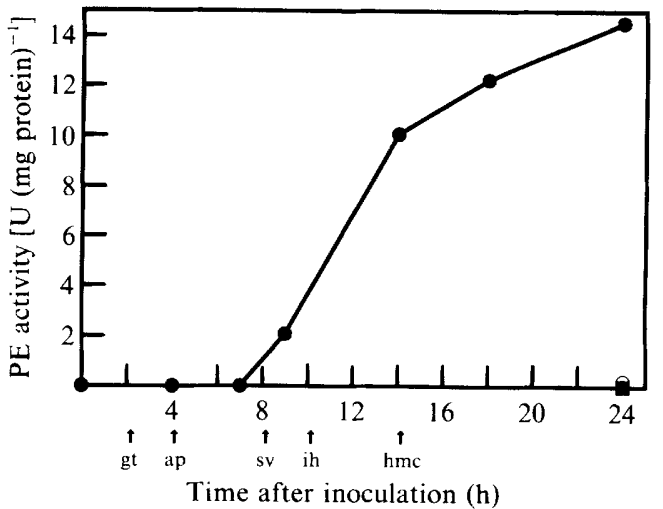

Fig. 1. Expression of pectinesterase (PE) activity in crude extracts of differentiated $(\odot)$, non-differentiated $(\square)$, and cycloheximide-treated (O) uredosporelings of $U$. viciae-fabae at different times after inoculation. Occurrence of germ tubes (gt), appressoria (ap), substomatal vesicles (sv), infection hyphae (ih) and haustorial mother cells $(\mathrm{hmc})$ is indicated by arrows.

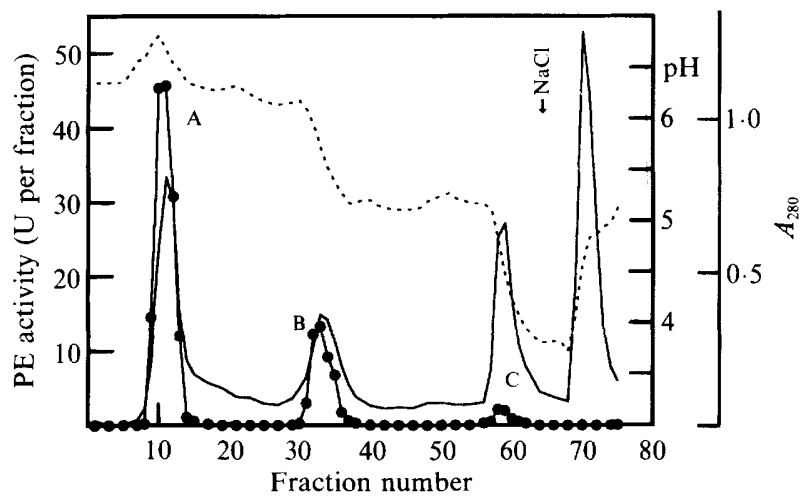

Fig. 2. Chromatofocusing of a crude extract prepared from 24-h-old differentiated uredosporelings of $U$. viciae-fabae on $\mathrm{DEAE} \mathrm{Si}=500$. Pectinesterase (PE) activity (- - ), absorbance at $280 \mathrm{~nm}(\longrightarrow)$ and the $\mathrm{pH}$ gradient (- - ) are shown. Activity peaks of isoforms A, B, and $\mathrm{C}$ are marked.

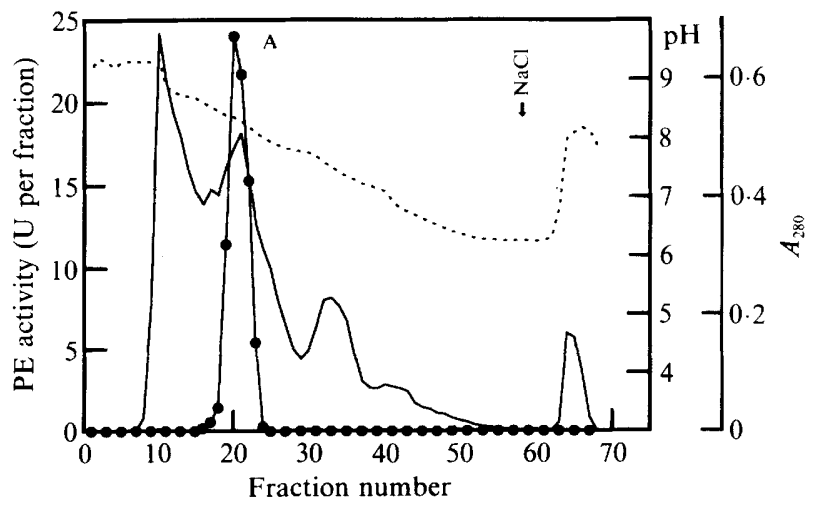

Fig. 3. Chromatofocusing of pectinesterase peak A from Fig. 2 on PBE 94. Pectinesterase (PE) activity (- - ), absorbance at $280 \mathrm{~nm}$ (-), and the $\mathrm{pH}$ gradient (-- ) are shown. 
Table 1. Secretion of pectinesterase activity by U. viciae-fabae

Enzyme activities (PE, pectinesterase; $\mathrm{MDH}$, malate dehydrogenase) or the protein yield in extracts and washing fluid were added to give overall values that were taken as $100 \%$. The values in parentheses represent percentages of this total.

\begin{tabular}{|c|c|c|}
\hline & Extract* & $\begin{array}{l}\text { Washing } \\
\text { fluid }\end{array}$ \\
\hline $\begin{array}{l}\text { Specific PE activity } \\
{\left[\mathrm{U}(\mathrm{mg} \text { protein })^{-1}\right]}\end{array}$ & 2.06 & $56 \cdot 7$ \\
\hline $\begin{array}{l}\text { Relative PE activity } \\
\text { (U per polyethylene membrane) }\end{array}$ & $2 \cdot 24(49 \cdot 7)$ & $2 \cdot 27(50 \cdot 3)$ \\
\hline $\begin{array}{l}\text { Relative } \mathrm{MDH} \text { activity } \\
\left(\Delta A_{340} \mathrm{~min}^{-1} \text { per polyethylene membrane }\right)\end{array}$ & $41 \cdot 0(99 \cdot 6)$ & $0.17(0.4)$ \\
\hline $\begin{array}{l}\text { Protein } \\
\text { (mg per polyethylene membrane) }\end{array}$ & $1.09(96.5)$ & $0.04(3.5)$ \\
\hline
\end{tabular}

* Extract of germlings scraped from a previously washed membrane.

Isoforms $\mathrm{A}$ and $\mathrm{B}$ revealed different $\mathrm{pH}$ optima. While isoform $\mathrm{A}$ showed a distinct $\mathrm{pH}$ optimum at $\mathrm{pH} 6 \cdot 0$, isoform $\mathrm{B}$ was most active in the range from $\mathrm{pH} 5.5$ to 7.5 (Fig. 4).

Addition of divalent cations such as $\mathrm{Ca}^{2+}, \mathrm{Mg}^{2+}$ and $\mathrm{Mn}^{2+}$ had no effect on the activity of isoforms A and B, and the addition of $10 \mathrm{~mm}$-EDTA did not reduce activity. Varying the $\mathrm{NaCl}$ concentration from $50 \mathrm{~mm}$ to $1 \mathrm{M}$ had no effect on the apparent pectinesterase activity, while $\mathrm{NaCl}$ concentrations lower than $50 \mathrm{~mm}$ reduced the apparent pectinesterase activity by some $20 \%$ (data not shown).

\section{Partial purification of pectinesterase isoform $A$}

In washing fluids the specific activity of pectinesterase was $\sim 25$ times higher than in crude extracts. Chromatofocusing of the concentrated washing fluid on PBE 94 led to a 23-6-fold enrichment of pectinesterase isoform A on a protein basis. However, pectinesterase activity was unstable and further purification steps were not attempted. After chromatofocusing of extracellular proteins, activity yields were only $34 \%$ of the activity in the washing fluid (Table 2). This was notably different from the $80-90 \%$ recovery rates on the same column when crude extracts were used (data not shown). The

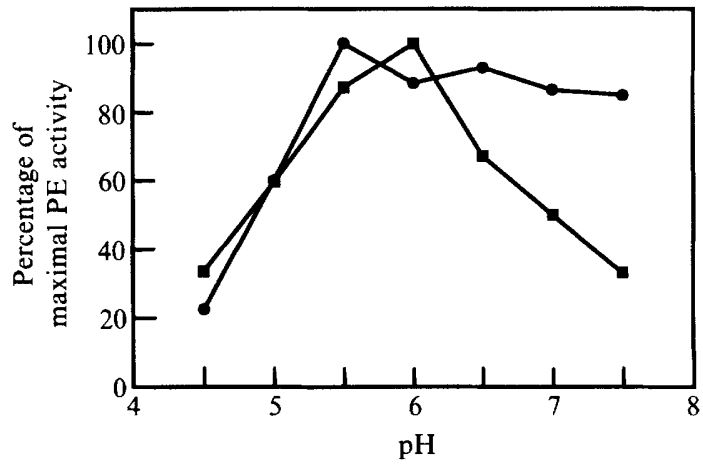

Fig. 4. pH profiles of activity of pectinesterase (PE) isoform $A(\boldsymbol{D})$ and isoform $\mathrm{B}(\mathrm{O})$ of $U$. viciae-fabae. The maximal activity of the respective isoform was set $100 \%$. Lower activities were expressed as percentages of maximal activity.

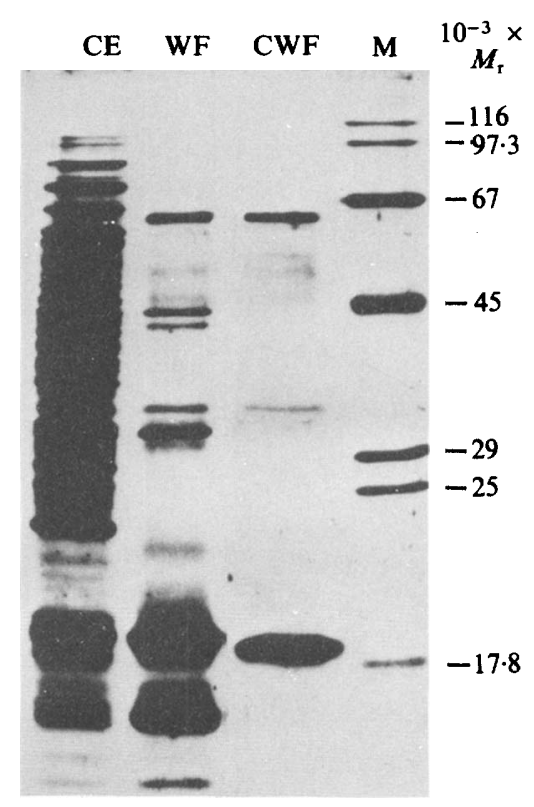

Fig. 5. Analysis by SDS-PAGE of crude extract (CE), washing fluid (WF), and fractions containing pectinesterase isoform $A$ activity after chromatofocusing of washing fluid on PBE 94 (CWF). Gels were loaded with $15 \mu \mathrm{g}$ (CE; WF) or $2 \mu \mathrm{g}$ (CWF) of protein, respectively. $M_{\mathrm{r}}$ markers (M) were $\beta$-galactosidase $\left(M_{\mathrm{r}} 116000\right)$, phosphorylase $b$ (97300), BSA (67000), egg albumin (45000), carbonic anhydrase (29000), chymotrypsinogen (25000), and horse myoglobin (17800).

Table 2. Partial purification of pectinesterase (PE) isoform A from U. viciae-fabae

\begin{tabular}{|c|c|c|c|c|}
\hline Step & $\begin{array}{c}\text { Total PE } \\
\text { activity (U) }\end{array}$ & $\begin{array}{c}\text { Yield } \\
(\%)\end{array}$ & $\begin{array}{c}\text { Specific PE } \\
\text { activity } \\
\left(\mathrm{U} \mathrm{mg^{-1 } )}\right.\end{array}$ & $\begin{array}{l}\text { Purification } \\
\text { factor }\end{array}$ \\
\hline PE isoform $\mathrm{A}$ after chromatofocusing (PBE 94) & $64 \cdot 5$ & $18 \cdot 6$ & $443 \cdot 0$ & $23 \cdot 6$ \\
\hline PE isoforms $B$ and $C$ after chromatofocusing (PBE 94) & $53 \cdot 5$ & $15 \cdot 5$ & $12 \cdot 2$ & $0 \cdot 6$ \\
\hline Total PE activity after chromatofocusing (PBE 94) & $118 \cdot 0$ & $34 \cdot 1$ & - & - \\
\hline
\end{tabular}


specific activity of isoform $\mathrm{A}$ after chromatofocusing of washing fluid on PBE 94 was 238 times higher than the pectinesterase activity of crude extracts of the same spore batches.

The partial purification of pectinesterase isoform $\mathrm{A}$ was examined on silver-stained SDS-gels (Fig. 5). Crude extracts led to an almost continuous stain in the $M_{\mathrm{r}}$ range from 70000 to 8000 and individual protein bands could not be distinguished. However, only 12 peptide bands were visible when washing fluids were separated on SDSPAGE. The pooled fractions containing pectinesterase isoform $\mathrm{A}$ after chromatofocusing of the washing fluid on PBE 94 revealed two prominent protein bands $\left(M_{\mathrm{r}}\right.$ 62000 and 18500$)$ and three faint protein bands $\left(M_{\mathrm{r}}\right.$ 54000,52000 and 33000).

\section{Discussion}

A large variety of necrotrophic fungi produce pectindegrading enzymes in order to invade plant tissue (Keon et al., 1987), and in some host-parasite interactions these enzymes are thought to influence the virulence of the pathogen (Köller et al., 1982; Lei et al., 1985; Cleveland \& Cotty, 1991). In obligate biotrophs, pectic enzymes have either not been found (Keon et al., 1987), or not been demonstrated beyond doubt (Van Sumere et al., 1957). In this report we have shown that in $U$. viciaefabae pectinesterases are formed only during germling differentiation, in the absence of pectin or other potentially inductive pectin degradation products. Pectinesterases are only expressed in fungal structures that in nature directly contact the pectin layer of mesophyll cells. To our knowledge, this type of regulation has not hitherto been reported for fungal pectic enzymes. In other systems pectic enzymes were shown to be either adaptive or constitutively expressed (Cooper, 1983). It is clear from the present investigation that in $U$. viciaefabae, pectinesterase production is regulated during morphogenic differentiation of sporelings. Thus, the apparent failure to demonstrate the production of pectic enzymes in rust fungi may be due to the fact that specific stages of germling morphogenesis were not studied.

The ability of rust sporelings to infect their hosts successfully correlates with their vitality and energy resources (Niks, 1990). Constitutive expression of pectinesterases during germ tube growth on the leaf surface would waste resources. On the other hand, a timeconsuming substrate induction of pectinesterases after contact with host pectin, could delay, and thus endanger, the formation of the first haustorium in the host leaf. Differentiation-specific regulation of pectinesterase appears to avoid both disadvantages and to favour successful germling morphogenesis.
In $U$. viciae-fabae, three isoforms of pectinesterase can be distinguished by their isoelectric points. The pIs of the isoforms $\mathrm{B}$ and $\mathrm{C}$ are acidic, whereas the $\mathrm{pI}$ of form $\mathrm{A}$ is weakly alkaline. Physicochemical properties determine the electrostatic interactions between extracellular enzymes of pathogens and the negatively charged carboxyl groups of the pectin of the plant mesophyll cells (Keon et al., 1987). Since the $\mathrm{pH}$ in the apoplast of mature leaf tissue is in the range 5.0-6.5 (Grignon \& Sentenac, 1991) the acidic isoforms $B$ and $C$ can be expected to be uncharged and thus freely diffusible. In contrast, isoform A would be positively charged, leading to adhesion to the negatively charged cell wall. Thus, the activity of isoform A would be limited to the host-parasite interface. We speculate that pectinesterase isoform A would efficiently prepare demethylated pectin specifically at the site of infection. The polygalacturonic acid would then serve as substrate for polygalacturonate lyase (EC 4.2.2.2), an enzyme that was recently demonstrated for $U$. viciaefabae (Deising \& Mendgen, 1992). Restriction of pectin degradation to relatively small areas of the host-parasite interface would cause minimal host tissue damage, a factor presumed to be necessary for successful biotrophy (Chong et al., 1981; Taylor \& Mims, 1991).

The main characteristics of the pectinesterase isoforms of $U$. viciae-fabae are similar to those reported for pectinesterases of other fungi. In the hemibiotroph Phytophthora infestans two different forms of pectinesterase were characterized (Förster \& Rasched, 1985). Pectinesterase type I of $P$. infestans exhibits a broad $\mathrm{pH}$ optimum like isoform B in U. viciae-fabae, while isoform A and pectinesterase type II of $P$. infestans show distinct $\mathrm{pH}$ optima. The $\mathrm{pH}$ optima and the $M_{\mathrm{r}}$ values of pectinesterases in $U$. viciae-fabae are in the range reported for other fungi such as $P$. infestans, Trichoderma reesei, Rhizoctonia solani and Botrytis cinerea (Förster \& Rasched, 1985; Marcovic et al., 1985; Marcus et al., 1986; Schejter \& Marcus, 1988). To our knowledge, no fungal pectinesterases with acidic $\mathrm{pI}$ values have so far been detected. In SDS-gels of fractions containing partially purified isoform A only one band, corresponding to an $M_{\mathrm{r}}$ of 33000 , was in the expected molecular mass range.

We thank Dr Ralph Nicholson for critically reading the manuscript and the Deutsche Forschungsgemeinschaft for grant no. ME 523-12-11 and no. ME 523-13-11.

\section{References}

Bateman, D. F. (1976). Plant cell wall hydrolysis by pathogens. In Biochemical Aspects of Plant-Parasite Relationships, pp. 79103. Edited by J. Friend \& D. R. Threlfall. London: Academic Press.

BRADFORD, M. M. (1976). A rapid and sensitive method for the quantitation of microgram quantities of protein utilizing the 
principle of protein-dye binding. Analytical Biochemistry 72, 248254.

Chong, J., HaRder, D. E. \& Rohringer, R. (1981). Ontogeny of mono- and dikaryotic rust haustoria: cytochemical and ultrastructural studies. Phytopathology 71, 975-983.

Cleveland, T. E. \& Cotty, P. J. (1991). Invasiveness of Aspergillus flavus isolates in wounded cotton bolls is associated with production of a specific fungal polygalacturonase. Phytopathology 81, 155158.

COOPER, R. M. (1983). The mechanisms and significance of enzymic degradation of host cell walls by parasites. In Biochemical Plant Pathology, pp. 101-135. Edited by J. A. Callow. New York: John Wiley.

COOPER, R. M. (1984). The role of cell wall-degrading enzymes in infection and damage. In Plant Diseases: Infection, Damage and Loss, pp. 13-27. Edited by R. K. S. Wood \& G. J. Jellis. Oxford: Blackwell Scientific Publications.

Deising, H. \& MENDGEN, K. (1992). Developmental control of enzyme production and cell wall modification in rust fungi, and defence reactions of the host plant. In Molecular Biology of Filamentous Fungi, pp. 27-44. Edited by U. Stahl \& P. Tudzynski. Weinheim: Verlag Chemie.

Deising, H., Jungblut, P. R. \& Mendgen, K. (1991). Differentiationrelated proteins of the broad bean rust fungus Uromyces viciae-fabae, as revealed by high resolution two-dimensional polyacrylamide gel electrophoresis. Archives of Microbiology 155, 191-198.

FöRSTER, H. \& RASCHED, I. (1985). Purification and characterization of extracellular pectinesterases from Phytophthora infestans. Plant Physiology 77, 109-112.

Grignon, C. \& SENTENAC, H. (1991). pH and ionic conditions in the apoplast. Annual Review of Plant Physiology and Plant Molecular Biology 42, 103-128.

HоCH, H. C. \& StaPles, R. C. (1987). Structural and chemical changes among the rust fungi during appressorium development. Annual Review of Phytopathology 25, 231-247.

JUNGBlUT, P. R. \& SEIFERT, R. (1990). Analysis by high-resolution twodimensional electrophoresis of differentiation-dependent alterations in cytosolic protein pattern of HL-60 leukemic cells. Journal of Biochemical and Biophysical Methods 21, 47-58.
Keon, J. P. R., BYRDE, R. J. W. \& COOPER, R. M. (1987). Some aspects of fungal enzymes that degrade plant cell walls. In Fungal Infection of Plants, pp. 133-157. Edited by C. F. Pegg \& P. G. Ayres. Cambridge: Cambridge University Press.

Köller, W., Allan, C. R. \& Kolattukudy, P. E. (1982). Role of cutinase and cell wall degrading enzymes in infection of Pisum sativum by Fusarium solani f. sp. pisi. Physiological Plant Pathology 20 , 47-60.

LAEMmLI, U. K. (1970). Cleavage of structural proteins during the assembly of the head of bacteriophage T4. Nature, London 227, 680685.

Lei, S.-P., Lin, H.-C., Heffernan, L. \& Wilcox, G. (1985). Evidence that polygalacturonase is a virulence determinant in Erwinia carotovora. Journal of Bacteriology 164, 831-835.

Marcus, L., Barash, I., SNeh, B., Koltin, Y. \& Finkler, A. (1986). Purification and characterization of pectolytic enzymes produced by virulent and hypovirulent isolates of Rhizoctonia solani Kuhn. Physiological and Molecular Plant Pathology 29, 325-336.

Markovic, O., Slezárik, A. \& Labudová, I. (1985). Purification and characterization of pectinesterase and polygalacturonase from Trichoderma reesei. FEMS Microbiology Letters 27, 267-271

Mendgen, K., Schneider, A., Sterk, M. \& Fink, W. (1988). The differentiation of infection structures as a result of recognition events between some biotrophic parasites and their hosts. Journal of Phytopathology 123, 259-272.

NiKs, R. E. (1990). Effect of germ tube length on the fate of sporelings of Puccinia hordei in susceptible and resistant barley. Phytopathology $80,57-60$.

SCHEJTER, A. \& MARCus, L. (1988). Isozymes of pectinesterase and polygalacturonase from Botrytis cinerea Pers. Methods in Enzymology 161, 366-373.

TAYLOR, J. \& MiMS, C. W. (1991). Fungal development and host cell responses to the rust fungus Puccinia substriata var. indica in seedling and mature leaves of susceptible and resistant pearl millet. Canadian Journal of Botany 69, 1207-1219.

Van Sumere, C. F., Van Sumere-De Preter, C. \& Ledingham, G. A. (1957). Cell-wall splitting enzymes of Puccinia graminis var. tritici. Canadian Journal of Microbiology 3, 761-770. 